\title{
Reaction in Ontario to Bill 110: Canada's first mandatory gunshot wound reporting law
}

\author{
Howard Ovens, MD; ${ }^{*}$ Hannah Park, BSc; ${ }^{\dagger}$ Bjug Borgundvaag, PhD, MD*
}

See related article on PAge 64

\begin{abstract}
Objective: With the proclamation of Bill 110 in September 2005, Ontario became the first jurisdiction in Canada to mandate that gunshot wounds (GSWs) be reported to authorities. We sought to evaluate the impact of Bill 110, including the awareness of, experience with and opinions about the new law among Ontario emergency physicians (EPs), the public and the police.

Methods: An online survey was distributed to all members of the Section on Emergency Medicine at the Ontario Medical Association. The public survey consisted of 3 closed questions and was performed by the polling firm Ipsos-Reid by telephone. Police opinion was requested through the Ministry of Community Safety and Correctional Services of the Ontario government.

Results: The physician response rate was $25 \%$. The great majority of respondents were aware of the law $(93 \%)$ and willing to comply $(88 \%)$, but only half were sure of their obligations and the penalties. Since the law had been proclaimed, the majority $(51 \%)$ had seen at least $1 \mathrm{GSW}$ victim. Seventy-nine percent reported no problems with either the police or the bill, and $86 \%$ perceived no change in relations with patients. Six incidents of patients delaying care were reported. Of the public surveyed, two-thirds were aware of the law. After being informed of the law, almost all (95\%) expressed support, and the majority $(80 \%)$ felt it would not change their relationship with their treating physician. All 47 members of the Ontario Provincial Police who were surveyed agreed that Bill 110 is helpful for shooting investigations, 8 reported that they had personally been involved in cases initiated by a report and 6 had been involved in cases where charges were laid or weapons confiscated. Data on actual reports and results of investigations were not available.

Conclusion: Bill 110 seems to have been broadly accepted by the emergency community and endorsed by the public.

Keywords: gunshot wound, reporting, Ontario Bill 110

\section{RÉSUMÉ}

Objectif : Avec la promulgation de la Loi de 2005 sur la déclaration obligatoire des blessures par balle (BPB), I'Ontario est devenue la première province du Canada à rendre obligatoire la divulgation de BPB aux corps de police. Nous avons cherché à évaluer l'impact de cette loi, y compris la connaissance de la loi, l'expérience en matière de son application et les opinions à son égard auprès des médecins d'urgence de l'Ontario, du public et des corps de police.
\end{abstract}

From the *Department of Emergency Services, Mount Sinai Hospital, Toronto, Ont., and the HFaculty of Medicine, University of Toronto, Toronto, Ont.

Submitted May 21, 2008; Revised Oct. 30, 2008; Accepted Nov. 2, 2008

This article has been peer reviewed.

CJEM 2009;11(1):3-13 
Méthode : On a mené une enquête en ligne auprès de tous les membres de la section de médecine d'urgence de l'Association médicale de l'Ontario (AMO). La firme de sondage Ipsos-Reid a réalisé l'enquête téléphonique auprès du public; elle comportait 3 questions fermées. Les opinions des corps de police ont été recueillies par l'intermédiaire du Ministère de la Sécurité communautaire et des Services correctionnels du gouvernement de l'Ontario.

Résultats : Le taux de réponse des médecins était de $25 \%$. La grande majorité des répondants connaissaient la loi (93\%) et acceptaient de s'y conformer (88\%), mais seulement la moitié connaissaient bien leurs obligations et les sanctions en cas de non-respect. Depuis la promulgation de cette loi, la majorité des médecins (51\%) avaient traité au moins 1 victime de BPB. Soixante-dix-neuf pour cent ont rapporté n'avoir eu aucun problème avec les policiers ou la loi, et $86 \%$ n'ont perçu aucun changement dans les rapports avec les patients. Six incidents de patients ayant tardé à obtenir des soins ont été signalés. Deux-tiers des citoyens interrogés connaissaient cette loi. Après avoir été mise au courant de la loi, la quasi-totalité ( $95 \%$ ) a exprimé son soutien, et la majorité $(80 \%)$ d'entre eux ont estimé que la loi n'aurait pas d'effet sur leur rapport avec leur médecin traitant. Les 47 membres de la Police provinciale de l'Ontario qui ont été interrogés étaient tous d'avis que la loi est utile en cas d'enquêtes impliquant l'utilisation d'une arme à feu; 8 ont déclaré avoir personnellement ouvert une enquête à la suite d'une déclaration de BPB et 6 ont traité des cas où des accusations avaient été portées ou des armes avaient été confisquées. Les données sur les rapports et les résultats des enquêtes n'étaient pas accessibles.

Conclusion : Il semble que les médecins d'urgence aient largement accepté la Loi de 2005 sur la déclaration obligatoire des BPB et que le public soit en faveur de cette loi.

\section{Introduction}

With the proclamation of Bill 110 in September 2005, Ontario became the first jurisdiction in Canada to mandate that gunshot wounds (GSWs) be reported to authorities. ${ }^{1}$ Under the legislation, when a patient presents to a health care facility with a GSW, someone at that facility (medical, nursing or clerical staff) is obliged to report the patient's presence in the facility and his or her identity (no other information can or should be given) to the local police. There is no penalty for failure to report. ${ }^{2}$ The legislation was meant to improve public safety by aiding police investigations, promoting injury prevention and reducing conflicts between health care workers and the police. ${ }^{3}$

Bill 110 was introduced by the Ontario government soon after the Ontario Medical Association's (OMA's) Section on Emergency Medicine published its position statement calling for mandatory reporting of GSWs. ${ }^{3}$ The position statement was developed by the section's executive in response to anecdotes of conflict between police and emergency physicians (EPs) over access to identifying information on GSW victims. A literature review revealed that there were theoretical benefits to mandatory reporting. Although there was little published evidence on the outcomes of mandatory reporting legislation in other jurisdictions, in general, where the legislation existed, mandatory reporting was broadly accepted. A survey of Ontario physicians sug- gested mandatory reporting would be supported or accepted by the majority, leading to the position adopted by the executive. Both the position statement and the proposed bill were hotly debated in the medical and lay literature. ${ }^{4-10}$ Some critics of the law pointed out that the majority of GSWs are accidental or self-inflicted, and suggested that education regarding safe firearm handling and psychiatric help where appropriate could be more effective for promoting public safety than mandatory reporting. ${ }^{6}$ Others expressed fears that some patients might avoid seeking medical care for fear of being reported, and that patients in general could be more reluctant to disclose illegal or sensitive information to their physician, such as illicit substance abuse or sexual history. ${ }^{6,7}$

Two years after the law's proclamation, we felt enough experience had been gained to evaluate the impact of and response to this new law. In part 1 of our study, we surveyed EPs registered with the OMA Section on Emergency Medicine regarding the level of awareness and knowledge of Bill 110, their experience with the law and their compliance with its provisions. In part 2, we surveyed the general public in Ontario about knowledge of and opinions about Bill 110, and we surveyed the members of the Ontario Provincial Police (OPP) regarding their perspective on the impact of the law. This project was reviewed by the Mount Sinai Hospital Research Ethics Board, which determined that Research Ethics Board approval was not required. 


\section{Methods}

\section{Part 1: Survey of the Section on Emergency Medicine of the Ontario Medical Association}

Based on a previous survey of the OMA Section on Emergency Medicine in 2003, ${ }^{3}$ we developed a 20 -question survey instrument to assess attitudes about the mandatory reporting of GSWs. This survey instrument was piloted for clarity and consistency among a convenience sample of 15 local EPs working in both academic and community hospitals, and it was modified based on the feedback received. In July 2007, the final survey (Appendix 1) was distributed to the 1080 members of the OMA Section on Emergency Medicine with registered email addresses. The survey was conducted using a modified Dillman method (advance notification, 4 contact attempts) and was Webbased. All responses were kept anonymous and were encrypted during transmission to ensure confidentiality.

\section{Part 2: Survey of the general public and police}

We developed a simple 3-question survey instrument (Appendix 2). These questions were edited for clarity in collaboration with Ipsos-Reid and piloted on a convenience sample of friends and family for clarity and consistency. The survey was conducted on a representative, randomly selected sample of 1001 Ontarians as part of an Ipsos-Reid Omnibus public opinion survey between July 16 and July 28, 2007. The typical response rate for an Ipsos-Reid telephone survey is between $6 \%$ and $11 \%$. These data were weighted to ensure that the sample's regional, age and sex composition reflected that of the actual Ontario population according to census data.

It was not possible to directly survey members of Ontario's police force regarding the impact of Bill 110. However, the staff of the Ministry of Community Safety and Correctional Services assisted in distributing our survey (Appendix 3) to representatives of the Ontario Association of Chiefs of Police (OACP) and the OPP. The survey was distributed to 47 bureau commanders or others who were identified as the police officers most likely to have had experience with Bill 110 ( S/Sgt. Lori Doonan, Executive Officer, Office of the Bureau Commanders, Orillia, Ont.: personal communication, 2007).

\section{Statistical analysis}

Data were entered into an Excel (Microsoft Corp.) spreadsheet and imported into SAS Version 9.1 (SAS Institute, Inc.) for analysis. We employed simple descriptive statistics to describe our sample population and used nonparametric tests of association $\left(\chi^{2}\right)$ for univariate analysis of demographic factors with individual responses.

\section{Results}

\section{Part 1: Survey of the Section on Emergency Medicine of the Ontario Medical Association}

Of the 1080 surveys sent out to members of the OMA's Section on Emergency Medicine, 267 were returned, yielding a response rate of $25 \%$. The demographics of survey respondents are described in Table 1. Respondents were given the option to not answer demographic questions and 7 respondents opted out. Respondent's knowledge,

\begin{tabular}{|c|c|c|}
\hline \multirow{2}{*}{$\begin{array}{l}\text { Characteristic } \\
\text { Sex }\end{array}$} & \multicolumn{2}{|c|}{$\begin{array}{l}\text { No. (\%) of physicians } \\
\qquad n=260^{*}\end{array}$} \\
\hline & & \\
\hline Male & 192 & $(73.8)$ \\
\hline Female & 68 & $(26.1)$ \\
\hline \multicolumn{3}{|l|}{ Age, yr } \\
\hline $25-34$ & 38 & $(14.6)$ \\
\hline $35-44$ & 123 & $(47.3)$ \\
\hline $45-54$ & 72 & $(27.7)$ \\
\hline $55-64$ & 24 & $(9.2)$ \\
\hline$>65$ & 3 & (1.1) \\
\hline \multicolumn{3}{|l|}{ Work status } \\
\hline Casual & 10 & (3.8) \\
\hline Part-time & 61 & $(23.5)$ \\
\hline Full-time & 189 & $(72.7)$ \\
\hline \multicolumn{3}{|l|}{ Training } \\
\hline CCFP & 33 & $(12.7)$ \\
\hline CCFP (EM) & 115 & $(44.2)$ \\
\hline FRCPC & 55 & $(21.1)$ \\
\hline Other & 24 & $(9.2)$ \\
\hline $\begin{array}{l}\text { No specific training in emergency } \\
\text { medicine }\end{array}$ & 33 & $(12.7)$ \\
\hline \multicolumn{3}{|l|}{ Years in practice } \\
\hline$<5$ & 52 & $(20.0)$ \\
\hline $5-10$ & 64 & $(24.6)$ \\
\hline $11-15$ & 47 & $(18.1)$ \\
\hline $16-20$ & 40 & $(15.4)$ \\
\hline$>20$ & 57 & $(21.9)$ \\
\hline \multicolumn{3}{|l|}{ Main location of practice } \\
\hline Academic centre & 78 & $(30.0)$ \\
\hline Community hospital & 129 & $(49.6)$ \\
\hline Regional trauma centre & 23 & $(8.8)$ \\
\hline Rural hospital & 30 & $(11.5)$ \\
\hline \multicolumn{3}{|l|}{ Size of community } \\
\hline$<5000$ & 5 & (1.9) \\
\hline $5000-20000$ & 24 & $(9.2)$ \\
\hline $20000-100000$ & 46 & $(17.7)$ \\
\hline $100000-250000$ & 49 & $(18.8)$ \\
\hline $250000-500000$ & 40 & $(15.4)$ \\
\hline$>500000$ & 96 & $(36.9)$ \\
\hline
\end{tabular}

*Of the 267 respondents, 7 declined to provide their demographic data. 
awareness of the law and attitudes toward GSWs and reporting are displayed in Table 2 and Table 3. Respondents' experience with GSWs in the 2 years since the passage of the bill is summarized in Table 4 . The largest cohort of respondents $(n=64,24 \%)$ had been practising EPs for 5-10 years, and 207 (79\%) respondents had encountered at least $1 \mathrm{GSW}$ during their career. In the 2 years since the passage of Bill 110, 137 (51\%) respondents had seen at least $1 \mathrm{GSW}$, and 41 of these (30\%) had personally reported at least $1 \mathrm{GSW}$ to police. Among all respondents, $32(12 \%)$ indicated they would not report the presence of a GSW victim because it was a violation of patient confidentiality, but only 20 of these 32 were aware of the law (and 16 of these were unsure of the details of the law).

Since the passage of Bill 110, only 6 (4\%) EPs who had seen a GSW that had been reported to the police felt that the law had a negative impact on the patient-physician relationship. The great majority (97\%) stated that they had not encountered any patients who deferred seeking medical attention out of fear of being reported. Seven respondents had cared for a patient who delayed care out of fear of being reported. In 6 of these cases, the patients had been aware of the law. Reasons for finally seeking care included concern about infection of the wound or being approached by the police because of a related or unrelated event. In one reported case, the patient was unaware of the mandatory reporting law. After learning of the law, the patient expressed regret at having sought care as the wound had been sustained accidentally at the hands of an intoxicated friend.

Finally, respondents were given an opportunity to comment

Table 2. Respondentsí knowledge and awareness of Bill 110

\begin{tabular}{|c|c|}
\hline Knowledge and awareness & $\begin{array}{l}\text { No. }(\%), \\
n=267\end{array}$ \\
\hline Aware of the law & $248(93)$ \\
\hline Will comply with the law in a GSW case & $235(88)$ \\
\hline $\begin{array}{l}\text { Understood obligations and penalties under } \\
\text { the law }\end{array}$ & $133(50)$ \\
\hline GSW = gunshot wound. & \\
\hline
\end{tabular}

on Bill 110. A total of 58 comments were collected, which could be broken up into 5 general themes: 1) those who support the law in full $(27) ; 2$ ) those who partially support the law (13); 3) those who do not support the law (14); 4) those who had inquiries regarding the details of the law (6); and 5) other comments. There were many comments strongly supporting the public interest in these situations, while those who did not support the law generally felt it would be ineffective or were concerned with the violation of confidentiality. If we combine the 20 respondents who would not report a GSW victim despite being aware of the law with the 14 respondents who made comments opposed to the law (including 2 who also said they would not report), we find 32 doctors (12\%) clearly opposed to the law, 20 of whom (8\%) who said they were willing to defy it. In total, 55 respondents $(21 \%)$ expressed some reservations or opposition to Bill 110.

\section{Part 2: Survey of the general public and police}

The public opinion survey included 3 questions, which are shown with their respective responses in Table 5. Overall there was strong public support for mandatory reporting, with $948(95 \%)$ of respondents agreeing with the law. Only $43(4 \%)$ respondents disagreed with the law, and disagreement was correlated with younger age and male sex $(p<0.005)$. Fourteen of the 43 who disagreed with the law $(33 \%)$ were in the youngest age group (18-24 yr). Respondents in the lowest socioeconomic group were significantly more likely to report that Bill 110 would alter their relationship with their physician.

\section{Police opinions}

With the assistance of the Ministry of Community Safety and Correctional Services, our survey was distributed to representatives of the OACP and the OPP. The chiefs, in lieu of completing the survey, wrote to us stating that there "was strong consensus among the police leaders ... that Bill 110 has been beneficial ... and no concerns have been raised by our members ..." (Chief William Blair, President, OACP,

Table 3. Respondents' attitudes about gunshot wound reporting

\begin{tabular}{|c|c|c|c|c|c|}
\hline \multirow{2}{*}{ Statement: Bill 110 has: } & \multicolumn{5}{|c|}{ Group, no. (\%), $n=264^{*}$} \\
\hline & $\begin{array}{l}\text { Strongly } \\
\text { agree }\end{array}$ & $\begin{array}{l}\text { Somewhat } \\
\text { agree }\end{array}$ & $\begin{array}{l}\text { Neither agree } \\
\text { nor disagree }\end{array}$ & $\begin{array}{c}\text { Somewhat } \\
\text { disagree }\end{array}$ & $\begin{array}{l}\text { Strongly } \\
\text { disagree }\end{array}$ \\
\hline Reduced conflicts between HCWs and police & $44(16.7)$ & $75(28.4)$ & $127(48.1)$ & $11 \quad(4.2)$ & $(2.6)$ \\
\hline Improved public safety & $48(18.2)$ & $90(34.0)$ & 88 (33.3) & $26 \quad(9.9)$ & $12 \quad(4.6)$ \\
\hline Made my job easier & $53(20.1)$ & $80(30.3)$ & $93(35.2)$ & $27(10.2)$ & $11 \quad(4.2)$ \\
\hline Decreased patient trust in physicians & $6 \quad(2.3)$ & $52(19.7)$ & $110(41.7)$ & $69(26.1)$ & $27 \quad(10.2)$ \\
\hline
\end{tabular}


Toronto, Ont.: personal communication, 2007).

All 47 OPP officers to whom the survey was distributed responded. Forty-two identified themselves as "front-line officers" and 5 indicated that they were involved primarily in "administration." Eight respondents acknowledged not knowing what information was reportable under Bill 110. Eight had personally been involved in an investigation prompted by a report under Bill 110, and 6 of these stated that these investigations led to charges, confiscation of weapons or both. Ten respondents were aware of cases initiated by reports, and 8 of these respondents indicated the reports led to charges, confiscation of weapons or both, although we could not determine whether there was duplicate reporting of cases. All 47 who answered the question felt that Bill 110 was helpful in the investigations of shootings, 33 felt it had improved public safety and 28 felt it had

\begin{tabular}{|c|c|}
\hline Bill 110 in practice & No. $(\%)$ \\
\hline Report was made to the police & $112(82)$ \\
\hline Report made by emergency physician & $41(30)$ \\
\hline $\begin{array}{l}\text { Have encountered problems with reporting } \\
\text { GSWs (e.g., police trying to obtain more } \\
\text { information than permitted by law) }\end{array}$ & $15(11)$ \\
\hline
\end{tabular}

improved police relations with health care workers. The comments we received generally supported the bill as essential (8), emphasized the resolution of a dilemma for health care workers wishing to cooperate (7) or both. Three suggested extending the bill to other types of assault.

\section{Discussion}

The proclamation of Bill 110 in September 2005 made Ontario the first jurisdiction in Canada to enact legislation mandating the reporting of GSWs by health care facilities. ${ }^{2}$ The bill was supported by both the Ontario government and the opposition, by the police ${ }^{10,11}$ and by editorials in major newspapers, ${ }^{8,9}$ but was opposed by some in the health care field who were concerned about the need for and effectiveness of the bill, its potential impact on vulnerable members of the public and its potential effect on patient-physician relations. ${ }^{2,4,6,7,10}$

EPs had recommended that mandatory reporting be accompanied by a public database of reports and their outcomes. ${ }^{3}$ This was not done because of privacy concerns (Minister Monte Kwinter, Ontario Ministry of Community Safety and Correctional Services: personal communication, 2005) making it difficult to assess the real impact of the bill in terms of, for example, the number of reports, resulting charges and number of guns confiscated. In lieu of this we elected to seek the experience and opinions of the

Table 5. Results of public opinion survey

Survey question

No. (\%) of responses, $n=1001$

In Ontario, if you are injured by a gun, either accidentally or intentionally, and you go to a

hospital, do you believe that the hospital is ...

Allowed to call the police and report your arrival $\quad 274$ (27)

Obliged to call the police and report your arrival $\quad 648$ (65)

Prohibited from calling the police and reporting your arrival $\quad 58(6)^{*}$

Did not respond

$21 \quad(2)$

In Ontario, Bill 110 was passed in 2005, which made it mandatory for the hospital to report

all patients arriving with a GSW to the police. How do you feel about this law? $(n=1001)$

I agree with the law

$948 \quad(95)$

I disagree with the law $\quad 43$ (4)†

Had no opinion

$10 \quad(1)$

Given this new law, how likely is it that you will change your relationship with your doctor,

for example, making you less likely to trust your doctor with sensitive private information?

Very likely

Somewhat likely

101 (10)‡

Somewhat unlikely

$81 \quad(8) \ddagger$

Very unlikely

$126(13)$

Did not respond or had no opinion

679 (68)

$14 \quad(1)$

GSW = gunshot wound

*Significant $(p<0.05)$ correlation with age $(18-24 \mathrm{yr})$, marital status (single/never married) and being unemployed.

tSignificant $(p<0.05)$ correlation with age $(18-24 \mathrm{yr})$, and male sex.

$\neq$ Significant $(p<0.05)$ correlation with annual income $(<\$ 20000)$. 
major stakeholders who were affected by the law: EPs, the police and the public.

The results of our study suggest overall support and acceptance of the law by physicians, police and the public. Although we found anecdotal evidence of altered behaviour by shooting victims, the majority of physician and public respondents did not perceive any impact on patient-physician relations. Our results suggest that Bill 110 resulted in a reduction in conflicts between health care workers and police, and provides at least anecdotal evidence of possible real benefits to public safety.

Critics of Bill 110 voiced several concerns before its introduction, most notably, that such legislation would be unethical because it would compromise patient-physician confidentiality. ${ }^{4,7}$ Our results suggest that, in fact, only a small minority of EP respondents (12\%) shared this point of view, with the balance of respondents expressing not only their overall awareness of the law, but also their willingness to comply with its provisions. That only half of the physician respondents clearly understood their obligations and the penalties under the law suggests that further education about Bill 110 is required.

The proportion of physicians who support the law closely mirrors that of the general public, who overwhelmingly understood that hospitals would or could report the presence of GSW victims to the police (94\%) and supported the law (95\%). Perhaps not surprisingly, the only demographic groups among the general public that predicted disagreement with the law were younger men from the lower socioeconomic status group, who were single or never married. However, even in this group a significant majority supported the law. A similar proportion of both EPs $(22 \%)$ and members of the public (19\%) felt that Bill 110 might alter the trust in the patient-physician relationship. But our methodology precludes understanding in what way. Given the high awareness of and overall support for mandatory reporting by both groups, this may represent a hypothetical concern as opposed to an actual one.

Six physicians reported an encounter with a patient who had apparently delayed seeking care in order to avoid being reported. One physician encountered a patient whose reaction highlights the dilemma at the heart of Bill 110: the patient stated that, had he known he would be reported, he would not have come to the ED, to avoid getting his friend in trouble. His friend had shot him accidentally while intoxicated. Perhaps the patient would in fact have delayed or avoided treatment had he been aware of Bill 110, perhaps not. As an innocent victim of an accident, many would defend his right to prompt and confidential care. However, the image of an intoxicated person handling a loaded gun in an unsafe manner would raise concerns for public safety to many and justify reporting as well.

Other criticism of the legislation was that it was not needed, would not be effective and would complicate the EP's job.? Our study found that more EPs expressed positive rather than negative opinions about the bill's impact on public safety and working relations with the police, and the majority agreed that it had made their jobs easier, with few feeling there had been a negative impact on patient relations. Physicians who provided information on GSWs since the passage of the bill believed that in every case, victims were either already known to police or reported by someone at the facility. Police respondents indicated that between 8 and 18 investigations were initiated, resulting in 6 to 14 cases in which charges were laid, weapons confiscated or both (our methodology cannot distinguish duplicate reports of the same cases). The most common inquiry was whether the law applies to pellet or BB gun injuries (the law is not specific on this point but authorities recommend erring on the side of reporting [Barb LeBlanc, Executive Director of Health Policy, OMA, Toronto, Ont.: personal communication, 2008]).

Not surprisingly, given their public position statement of $2004,{ }^{11}$ the OACP (through its association head) has expressed support for the bill and its impact on investigations and relations with health care workers. The survey of police officers, again, predictably, demonstrated high support for the bill and its impact.

Both Saskatchewan (September 2007) ${ }^{12}$ and Nova Scotia (December 2007) ${ }^{13}$ have recently proclaimed mandatory reporting laws and it seems likely that other provinces may consider similar initiatives in the future. A more detailed analysis of the impact of mandatory reporting would require a database of reports as originally called for. Given the interest in adopting mandatory reporting in other jurisdictions, consideration should be given to provincial or national databases that would meet privacy requirements so that further decisions on mandatory reporting in other provinces can be guided by the best evidence possible, including data on actual numbers of reports and outcomes of resulting investigations.

\section{Limitations}

There are several important limitations to our study. The low response rate for the physician survey may have led to sampling bias. The demographics of the nonrespondents are not available, but those that did respond appear to be representative of all sectors of the emergency community and very similar to the respondents of our own previous survey. Membership in the OMA is mandatory for physicians in 
Ontario. Members are requested to identify sections related to their practice and may select multiple sections with no additional cost. The Section on Emergency Medicine includes the vast majority of EPs in the province. Given the large number of respondents who had experience with shootings (137 [51\%] had encountered a GSW within the 2 years since the passage of the bill), and the similar response rate to our previous survey, ${ }^{3}$ it seems physicians were more likely to reply if they had relevant personal experience, strong opinions on the bill or both. Additionally, as in any survey, physician responses to some questions are subject to recall bias.

We were also limited by the lack of data on actual numbers of reports and outcome of police investigations; we used personal reports by physicians and police as a proxy. It was not possible to survey police officers directly and anonymously, so we relied on senior officers' and administrators' opinions regarding Bill 110. Therefore, respondents could have been selected for, or influenced in, their opinions as expressed in the survey. However, given the nature of the law, we doubt that this opinion would be very different from that of rank and file officers. Finally, although the Ipsos-Reid survey methodology is commonly used to gauge public opinion, our survey results may be limited by the low response rates typical in conducting this kind of telephone survey.

\section{Conclusion}

In this first-ever evaluation of the impact in Ontario of Bill 110, Canada's initial mandatory reporting of GSW legislation, we found strong support for and compliance with the bill among EPs, police and the public. A publicly accessible database of reports and their outcomes would allow for a better evaluation of the law's impact and should be considered in all jurisdictions that are enacting legislation to mandate GSW reporting, and before extending the legislation to other situations. Ontario EPs could benefit from better education on the provisions of Bill 110. Concerns regarding the impact of the bill on patient-physician relations among a small but significant minority of physicians and the public deserve further elucidation.

Acknowledgement: Our study was supported in part by a grant from the University of Toronto through a CREMS (Comprehensive Research Experience for Medical Students) Summer Scholarship for Hannah Park. We received no commercial support, and no author has any conflict of interest to declare.

The authors would like to acknowledge Dr. Rahim Moineddin, $\mathrm{PhD}$, for his assistance with statistical analysis and Mr. Sean
Simpson, Research Manager at Ipsos-Reid Public Affairs, for his assistance with the telephone survey.

Competing interests: None declared.

\section{References}

1. Kondro W. Gunshot wound reporting mandatory in Ontario. CMAJ 2005;173:242.

2. Bill 110, Mandatory Gun-shot Wounds Reporting Act, 1st Sess., 38th Leg., Ontario, 2005. Available: www.ontla.on.ca/bills/billsfiles/38_Parliament/Session1/b110ra.pdf (accessed 2008 Nov 24).

3. Ovens HJ, Morrison H, Drummond A, et al. The case for mandatory reporting of gunshot wounds in the emergency department. Toronto (ON): Ontario Medical Association; 2003. Available: www.oma.org/pcomm/OMR/nov/03gunshot.htm (accessed 2008 Nov 24).

4. Pauls MA, Downie J. Mandatory reporting of gunshot wounds: rebuttal. CMAJ 2004;170:1258.

5. Ovens $\mathrm{H}$. Why mandatory reporting of gunshot wounds is necessary. A response from the OMA's Executive of the Section on Emergency Medicine. CMAJ 2004;170:1256-7.

6. Pauls MA, Downie J. Shooting ourselves in the foot: why mandatory reporting of gunshot wounds is a bad idea. CMAJ 2004;170:1255-6.

7. Ovens HJ, Cass D. Reporting gunshot wounds. Should physicians be mandated to call police? Parkhurst Exchange 2004;12: 36-7.

8. Report gun wounds [editorial]. The Globe and Mail [Toronto] 2004 June 28;SectA:16.

9. Fighting gun crime [editorial]. Toronto Star 2004;June 24;A:28.

10. Mackay B. Gunshot wounds: the new public health issue. CMAJ 2004;170:780.

11. Mandatory report; social responsibility v. patient privacy [briefing paper]. Sault Ste. Marie (ON): Ontario Association of Chiefs of Police; 2004.

12. New rules for reporting gunshot and stab wounds set for September [news release]. Regina (SK): Government of Saskatchewan; 2008. Available: www.gov.sk.ca/news?newsId=8bb4c506 -ce54-4aff-b8a1-97eec2156328. (accessed 2008 Nov 24).

13. Bill 10, Gunshot and Stab Wounds Mandatory Reporting Act, 2nd Sess., 60th Leg., Nova Scotia, 2008. Available: www.gov .ns.ca/legislature/legc/bills/60th_2nd/3rd_read/b010.htm (accessed 2008 Nov 24).

Correspondence to: Dr. Howard Ovens, Mount Sinai Hospital, 600 University Ave., Rm. 206, Toronto ON M5G 1X5; fax 416586 4719; hovens@ mtsinai.on.ca

Continued on next page 


\section{Appendix 1. Survey of Ontario emergency physicians (Part 1 of 3)}

1. Please consider the following scenario:

A patient arrives at your emergency department in Ontario with a non-life-threatening gunshot wound to the thigh. $\mathrm{He}$ is cooperative, and is registered and treated. The patient informs you that his injury occurred accidentally while he was cleaning his firearm. Before the patient is discharged, a nurse asks you if you intend on reporting your gunshot wound patient to the police.

You respond to the nurse,
a. Yes, I will call and notify the police
b. Yes, could you (nurse) please call and notify the police?
c. No, because it is a violation of the patientís confidentiality

[Format: question 2 is not visible until question 1 is answered]

Comments:

2. In 2005, Ontario passed Bill 110, which mandated all injuries involving firearms to be reported to the police. Are you aware of this law?
a. Yes
b. No

Comments:

3. Do you understand your obligations and the penalties for failing to report under the law?
a. Yes
b. No
c. Not sure

Comments:

4. Have you ever encountered a gunshot wound patient in the emergency department during your career?
a. Yes
b. No

If the answer is NO skip to question 12.

Comments:

5. How many gunshot wound patients have you encountered in your emergency department in the past 2 years?
a. 0
b. 1-5
c. $>5$

If answer is 0 skip to question 12 .

Comments:

6. Of all the gunshot wound patients you have cared for in Ontario in the past 2 years, how many were reported to the police by emergency department staff?
a. 0
b. 1-5
c. $>5$

If answer is 0 , skip to question 12 .

Comments:

7. How many reports did you make personally?
a. 0
b. $1-5$
c. $>5$

Comments:

8. How many reports were made by another health care worker on a patient you cared for?
a. 0
b. $1-5$
c. $>5$

Comments: 


\section{Appendix 1. Survey of Ontario emergency physicians (Part 2 of 3)}

9. In how many cases were the police already present in the emergency department at the time of the report?
a. 0
b. $1-5$
c. $>5$

Comments:

10. In your experience reporting gunshot wounds, have you had problems or conflicts with the police (e.g., trying to obtain more information than permitted by the law)?
a. Yes
b. No
c. Not sure

Comments:

11. Bill 110, proclaimed in September 2005, made Ontario the first jurisdiction in Canada to mandate the reporting of the presence of a gunshot wound patient in the emergency department to the police. The obligation to report rests with the facility. The police are to be provided with any known identifying data only and there are no penalties for failure to report.

In your experience, what impact do you feel Bill 110 has had on your relationship with your gunshot wound patients?
a. Positive impact
b. No impact
c. Negative impact

Comments:

12. Have you seen a patient who deferred coming to emergency department with a gunshot wound due to a fear of being reported in the past 2 years?

a. Yes. If yes, please give details:

b. No

Comments:

13. Please read the following statements and indicate to what extent you agree or disagree with them:

I believe that making gunshot wounds reportable ...

Strongly agree Somewhat agree Neither agree nor disagree Somewhat disagree Strongly disagree Has reduced conflicts between health care workers and the police Has improved public safety

Has made my job easier

Has decreased patients' trust in physicians generally (e.g., less likely to disclose other confidential/criminal behaviour such as substance abuse, etc.)

Comments:

14. In the space provided below, please write any comments, opinions or concerns with regard to mandatory reporting of gunshot wound patients.

Comments:

Demographics:

We would now like to ask you a few questions about yourself and your work experience. Once again, please note that all information will be kept confidential.

1. Age
a. $<25$
b. $25-34$
c. $35-44$
d. $45-54$
e. $55-64$
f. $>65$

Comments: 


\section{Appendix 1. Survey of Ontario emergency physicians (Part 3 of 3)}

2. Sex

a. Male

b. Female

Comments:

3. What is your status as emergency department physician?
a. Full-time
b. Part-time
c. Casual

Comments:

4. What type of emergency department training have you received?
a. CCFP
b. $\operatorname{CCFP(EM)}$
c. FRCP
d. Other: Please specify
e. No specific emergency department training Comments:

5. How many years have you practised as an emergency physician?
a. $<5$ years
b. $5-10$ years
c. 11-15 years
d. $16-20$ years
e. $>20$ years

Comments:

6. In what type of hospital do you predominantly practise emergency medicine?
a. Academic centre
b. Community hospital
c. Rural hospital
d. Regional trauma centre

Comments:

7. Please indicate the size of the population in the community where you predominantly practise emergency medicine.
a. $<5000$
b. $5000-20000$
c. $20000-100000$
d. $100000-250000$
e. $250000-500000$
f. $>500000$

Comments: 


\section{Appendix 2. Survey of the Ontario public}

1. In Ontario, if you are injured by a gun either accidentally or intentionally, and you go to a hospital, do you believe that the hospital is ... [select one]

- Allowed to call the police and report your arrival

- Obliged to call the police and report your arrival

- Prohibited from calling the police and reporting your arrival

2. In Ontario, Bill 110 was passed in 2005 which made it mandatory for the hospital to report all patients arriving with a gunshot wound to the police. How do you feel about this law? [select one]

- I agree with the law
- I disagree with the law

- I have no opinion

3. Given this new law, how likely is it that this will change your relationship with your doctor, for example by making you less likely to trust your doctor with sensitive or private information? [select one]

- very likely

- somewhat likely

- somewhat unlikely

- very unlikely

\section{Appendix 3. Survey of the Ontario Association of Chiefs of Police and the Ontario Provincial Police}

This is a short survey for a study being conducted to evaluate Bill 110 .

Your answers are completely confidential and will be released only as summaries. Your participation in this study is completely voluntary.

Thank you very much for helping with this important study. Your help is greatly appreciated.

1. Do you know what patient information a health care facility must report under Bill 110 ?

Yes

No

2. Please select one that best describes your position.

Front-line officer (Please go to question 3)

Chief or administration (Please go to question 5)

3. Have you personally been involved in a gunshot wound case that was prompted by a report made by a health care facility?

Yes

No

4. Have you personally been involved in a gunshot wound case where a report made by a health care facility led to charges being laid and/or weapons being confiscated?

Yes

No

5. Do you know of any case where an investigation was started as a result of a report made by a health care facility about a gunshot wound?

Yes

No

6. Do you know of any case where a report made by a health care facility led to charges being laid and/or weapons being confiscated?

Yes

No

7. Overall, is your impression that Bill 110 is helpful to shooting investigations?

Yes

No

8. Do you feel that Bill 110 has improved public safety?

Yes

No

9. Do you feel Bill 110 has improved relations with health care workers?

Yes

No

10. In the space provided below, please write any comments, opinions or concerns with regard to Bill 110 . 